\title{
7. Conclusion: champions of change
}

This book has covered Russia's five largest oil companies: Rosneft, LUKOIL, Gazprom Neft, Surgutneftegas and Tatneft. The chapters dedicated to each of the companies sought to portray the companies and their resilience and ability to adapt to an evolving world.

In the book's introduction, we presented the hypothesis that Russian oil companies are not good at foreseeing and adapting to change. Several subsidiary assumptions supported this hypothesis. First, we conjectured that the unpredictability of post-Soviet society has caused Russian companies to live in the moment and eschew long-term planning, giving rise to a grab-and-run mentality in Russian business culture. Second, Russian companies have subsisted on their Soviet-era assets and infrastructure rather than investing in new exploration and production. Third, the predominance of Soviet-trained, elderly men in the Russian oil company management teams has precluded these companies from responding effectively to the challenges and demands of the contemporary world.

We selected several cross-cutting themes for the exploration of our hypothesis and assumptions in the company chapters. Some of these themes concerned the basic characteristics of the oil companies: organizational transparency, production strategy, corporate social responsibility (CSR), offshore and Arctic oil extraction, innovation and internationalization. Other themes related to the types of change that they had faced and how adept they had been at handling them: oil price fluctuations, sanctions, unconventional oil and climate policy.

In the next section, we provide an overview of the cross-cutting themes we have covered in the company chapters and draw a conclusion on the validity of the hypothesis we presented in the introductory chapter. In the spirit of Karl Popper (1959), our task is to attempt to shoot down our own hypothesis. And, as it turns out, that is exactly what we shall end up doing in this concluding chapter.

\section{CROSS-CUTTING THEMES}

\section{Internationalization}

Several of the top five Russian oil companies are actively involved in internationalization through cooperation with foreign companies in Russia and investments in other countries. They are also active in overseas upstream and 
downstream operations. Had there been no sanctions against Russia in connection with the conflict in Ukraine, internationalization would have proceeded even faster. However, the sanctions also encouraged the Russian companies to seek out Asian partners, further diversifying their international ties.

We used the following criteria to profile the internationalization of each company: the number of countries where the company is present (upstream and downstream), foreigners on the board of directors, foreigners on the management board and foreign oil company partners in Russia. Drawing on our review of these criteria for each company, we created Table 7.1 (see p. 184).

Our analysis indicates that of the five oil companies, Rosneft is the most internationalized, followed by LUKOIL, Gazprom Neft, Tatneft and finally Surgutneftegas. However, because of the sanctions, most of Rosneft's Western-based partners have wound down their cooperation with the company, meaning that over time, Rosneft may become less internationalized.

\section{CSR}

All the companies have extensive CSR activities, with four of them (Gazprom Neft, LUKOIL, Rosneft and Tatneft) reporting on CSR, while Surgutneftegas publishes environmental reports. Many of the CSR activities take the form of sponsoring local institutions and activities in the regions where the companies operate and are not directly related to the companies' core activities. This form of social support is a remnant of the Soviet system, in which a company was not considered a commercial entity but part of the local government administrative structure with little emphasis on the division of labour and checks and balances but expectations of support for local social infrastructure. Under socialism, oil companies were the founding fathers of oil towns in Western Siberia and had to take care of all aspects of the lives of their workers, including maintenance of waste management facilities, the local steam baths and support for cultural festivals. Many of them divested themselves of social functions when they were privatized, although they maintained some of the Soviet-style traditions because of their symbolic value among employees and local communities.

The different companies covered in this book engage in a wide range of activities that are incorporated under the CSR umbrella and reported on in their sustainability reports. Some of these reports reflect the traditional Soviet approaches, such as support for health facilities and cultural festivals, for example. Others tend to reflect more Western notions of CSR, such as investment in the supply chain capacities of local enterprises. Yet other reports emphasize the rights of local indigenous peoples, civil society organizations and - increasingly - investors. The ways Russian oil companies negotiate benefit-sharing agreements with indigenous peoples combines elements of the Soviet, Russian and international standards and values. 


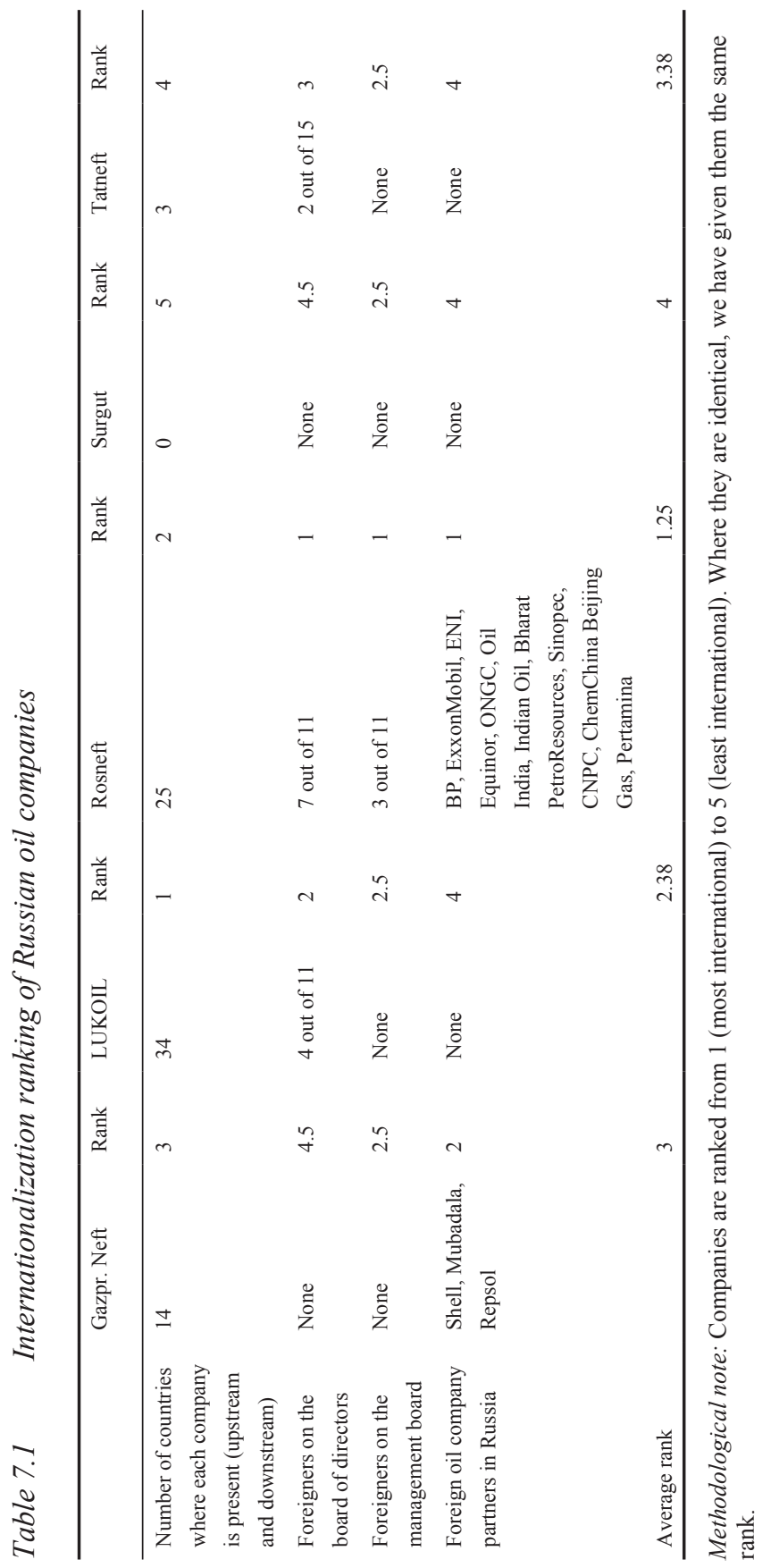




\section{Oil Price Fluctuations}

Due to oil price instability, the oil industry is one of the most changeable in the world, with extreme highs and lows. Oil price fluctuations are, therefore, the most important type of change with which any oil company has to grapple. Russian oil companies have handled the price hikes and collapses of the past 20 years surprisingly well. For the purpose of our analysis, the oil price collapse of 2014 is particularly interesting, as it coincided with Western sanctions targeting the Russian petroleum sector over Russia's involvement in the conflict in Ukraine. It was the perfect storm, and the result says something about Russian oil companies: They weathered the storm.

There are several reasons for the success of Russian oil companies in handling oil price fluctuations. The points listed here mostly concern the context in which the companies operate rather than relating to the Russian oil companies as organizations in their own right. First, even when oil prices were above USD 100 per barrel, for the Russian oil companies, these prices did not, in practice, exceed USD 35-40 because of the Russian revenue-based tax system (see the chapter on Gazprom Neft).

Second, as oil price fluctuations follow a cyclical pattern, conservative behaviour on the part of the oil companies can help them smooth out developments (not being too speculative when prices are high and not employing harsh cutbacks when they are low). The downside is that during a downturn, the Russian oil companies do not enjoy the same efficiency gains as their Western counterparts. The upshot is that the Russian oil companies are stable and resilient to price fluctuations but not world leaders.

Third, while the close linkage between the exchange rate of the Russian rouble and the oil price are detrimental to other parts of the Russian economy, it is highly beneficial for the Russian oil companies. When the oil price collapses, the rouble also tends to lose much of its value, greatly reducing their expenses.

Finally, after both the 2008 and 2014 oil price collapses, the state stepped in to provide financial aid to several companies. This was accomplished by reducing taxes and easing licensing and general pressure on the companies, on the one hand, and facilitating their access to capital, on the other.

\section{Sanctions}

Russia's oil majors also succeeded in coping with the 2014 Western sanctions over the conflict in Ukraine. Except for Tatneft, all the other companies covered in the book were targeted by the sanctions, and above all Rosneft. The companies' response to sanctions was sensible and included import substitution, a turn to new foreign partners in Asia and requests for financial assistance 
from the state. While the Russian oil companies suffered but survived the sanctions, the Chinese and Indian companies actually benefited from them since they managed to gain access to Russian assets at attractive prices.

Joint projects in the Arctic and offshore and unconventional oil that had been planned for implementation with Western-based companies were shelved. However, the projects that did not involve Western partners, such as Gazprom Neft's Arctic Prirazlomnoye field in the Pechora Sea and the work of Surgutneftegas and Tatneft on the Bazhenov shale formation in Western Siberia and on extra-viscous oil in Tatarstan, were carried out according to plan.

Overall oil production was little impacted by the sanctions. Figure 7.1 indicates a slight slowdown of oil production after the onset of the first wave of sanctions in early 2014. However, this may just as well have been due to the concurrent oil price collapse, and later also due to coordination between OPEC and Russia to cap output. Whatever caused Russian oil production growth to stagnate, it is clear that sanctions did not cause it to collapse. And by the end of 2018 it started rising again. A significant part of the reason for this can be found in Russia's oil majors' resilience to change. As oil price fluctuations are the most important type of change for oil companies, this undermines the hypothesis that Russian oil companies are bad at coping with change.

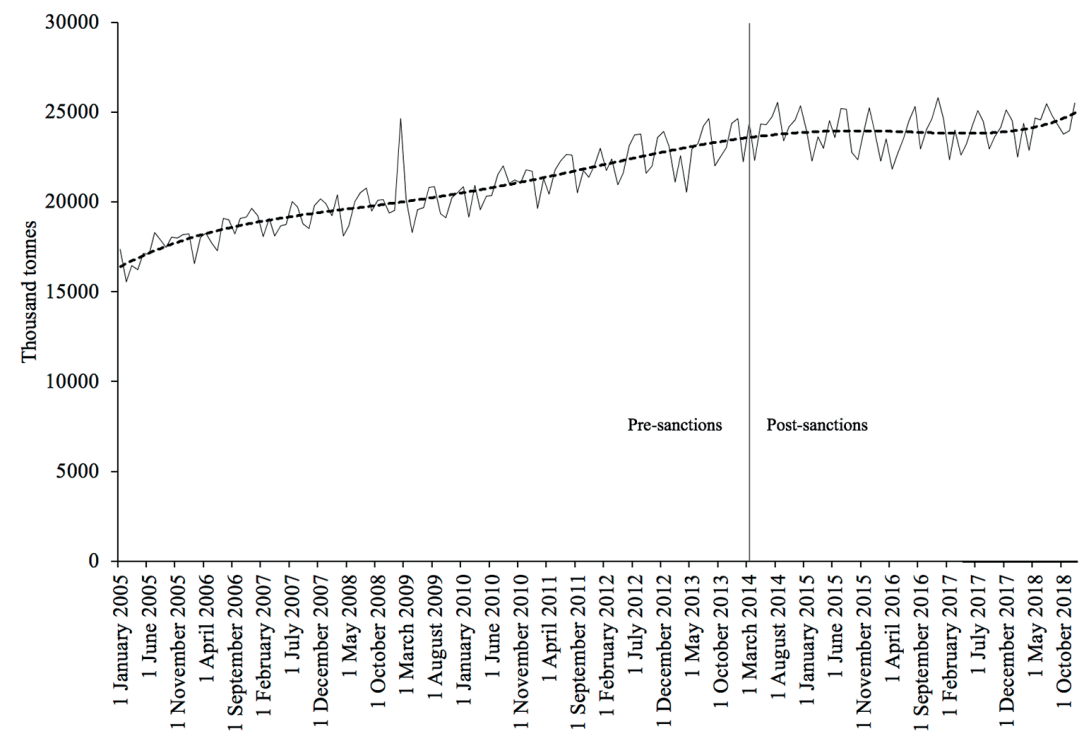

Figure 7.1 Russian oil production and sanctions

Source: GKS (2019); MinEnergo (2019). 


\section{Onshore and Offshore}

Until the imposition of sanctions in 2014, the Russian petroleum sector was a story of a landlubber trying to go to sea. The Russian oil and gas industry had a long history of onshore operations but with limited offshore experience. As the major oilfields discovered in the 1960s and 1970s were becoming depleted, the Russian oil companies tried to access Russia's offshore resources, which were expected to be significant, especially in the Arctic. To this end, they needed help from the international oil companies. Thus, the directing of sanctions at Russian offshore and Arctic developments can be interpreted as an attempt to hit where it hurts. In this regard, the sanctions were largely successful, especially in the case of the highly promising Kara Sea, which had to be shelved for the time being. However, Russia is a vast country and also has many onshore resources that can be exploited.

This short-term outlook aside, it takes a long time to discover and develop an oilfield, and in practice, the impact of the sanctions may not be felt for another decade or so after they were introduced in 2014 (Fjaertoft and Overland 2015). This situation may appear paradoxical mainly because the intention behind the sanctions was to punish Russia swiftly and severely for its role in Ukraine. However, as the Russian oil industry continues to evolve, locates new partners in China, India and other countries and sees an erosion of the will to uphold sanctions, it is unclear whether the sanctions will have a significant impact in the long run either. It is also unclear whether the new Asian partners can meet Russia's needs as successfully as the Western oil companies, given the profound international experience and cutting-edge petroleum technology of Western majors.

\section{Innovation}

Innovation is an important aspect of the ability to respond to the challenges of a changing world. President Putin has repeatedly called on the major Russian companies for greater innovation (Putin 2017), and Dmitry Medvedev made innovation the centrepiece of his presidency (Overland 2011). Nonetheless, there is a lingering impression that Russian oil companies are not innovative.

Although the Russian oil companies are far from being world leaders in petroleum technology, they have been trying to advance technologically. Among the five companies covered in this book, Gazprom Neft exhibits the greatest interest in innovation, including technologies to enhance well productivity, the development of the Bazhenov shale formation, oil recovery from depleted fields, manufacture of catalysts for refining and digitalization of oil production (see the chapter on Gazprom Neft). 
Concerning unconventional oil, two other Russian oil companies have innovative profiles: Surgutneftegas has a long record of extracting unconventional oil from the Bazhenov formation, and Tatneft seeks to gain as much as possible from its super-viscous fields (see the chapters on Surgutneftegas and Tatneft). However, a perennial challenge for the development of unconventional oil in Russia has been the country's extensive resources but limited effort to extract them. As the conventional resources in Western Siberia decline and new discoveries become less frequent, more companies may eventually find that they are forced to learn how to extract unconventional oil.

\section{Climate Change and Energy Policy}

In the long term, the most challenging change faced by oil companies - Russian or international - may be that of climate policy. Most of the five companies covered in this book have, at best, an ambivalent attitude towards climate change. In the terminology of Sherlock Holmes, this is a case of dogs that did not bark. It was difficult for us to find data on the positions of the companies on climate change, and this difficulty is in itself a sign that they are not proactive in this area. Their main real contribution, if any, is limiting the flaring of associated petroleum gas, which is required by the Russian authorities in order to maximize the use of Russia's natural resources.

However, a slight tendency for greater attention to climate change among the companies can be discerned in both their public statements and various publicly available company reports (see the chapter on Rosneft). Nonetheless, similar to many of their foreign peers, the Russian oil companies still believe that fossil fuels are here to stay.

Of all the companies, LUKOIL leads on reporting on greenhouse gas (GHG) emissions, utilization of associated petroleum gas, introduction of energy efficiency measures and preliminary steps concerning renewable energy, mostly outside Russia. Gazprom Neft has been similarly positioned, although in 2018 its utilization of associated petroleum gas declined again. In this regard, they follow the same trajectory as their international peers, lagging perhaps 10-15 years behind European companies, such as Equinor, Shell and Total but only a few years behind the American corporations.

\section{Transparency}

We found that most of the Russian oil companies are relatively transparent in their operations. This is especially true of those that are listed on foreign stock exchanges and thus required to share detailed financial information. We assessed the transparency of the five companies in several areas: recent regular international reserve audit, recent regular reporting under interna- 
tional accounting standards (IAS), clear public information on shareholders, information on share ownership by members of the board of directors and/ or top managers, operating data on fields and wells, sustainability reports in accordance with the Global Reporting Initiative (GRI), earliest financial annual report and number of press releases in 2018.

Drawing on our review of these areas, we ranked the transparency of the five companies and found that most of them were very transparent (Table 7.2).

Table 7.2 Transparency ranking of Russian oil companies

\begin{tabular}{|c|c|c|c|c|c|}
\hline & Gazp. Neft & LUKOIL & Rosneft & Surgut & Tatneft \\
\hline A. Recent regular international reserve audit & 1 & 1 & 1 & 0 & 1 \\
\hline B. Recent regular IAS statements & 1 & 1 & 1 & 1 & 1 \\
\hline C. Clear data on shareholders & 1 & 1 & 1 & 0 & 0.5 \\
\hline $\begin{array}{l}\text { D. Data on share ownership by the board of } \\
\text { directors' members and/or top managers }\end{array}$ & 1 & 1 & 1 & 1 & 1 \\
\hline E. Operating data on fields and wells & 1 & 1 & 0 & 0 & 0 \\
\hline $\begin{array}{l}\text { F. Sustainability reports in accordance with } \\
\text { GRI }\end{array}$ & 1 & 1 & 1 & 0 & 0 \\
\hline $\begin{array}{l}\text { G. Earliest financial annual report and number } \\
\text { of press releases in } 2018\end{array}$ & 0.95 & 0.7 & 0.59 & 0.07 & 0.82 \\
\hline H. Overall score & 5.70 & 4.20 & 2.95 & 0.14 & 2.87 \\
\hline
\end{tabular}

Notes:

A-F: $1=$ yes, $0=$ no

G: Earliest annual financial report available on the website. Number of press releases in 2018: normalized and averaged.

$\mathrm{H}$ : (sum of A-F) * G

\section{MASTERS OF ADAPTATION}

We hypothesized that Russian oil companies might not be good at foreseeing and handling change but in fact they have dealt with more of it - and done so no less successfully - than their Western counterparts. In the two decades from 1998 to 2018, Russian oil companies had to contend with the oil price drop and the collapse of the Russian economy in 1998, the gangster capitalism of the 1990s and the authoritarian capitalism of the 2000s and 2010s. The arrest of the country's once richest oilman, Mikhail Khodorkovskiy, in 2003 had a considerable impact; as did Rosneft's takeover of four of the best known Russian oil companies. The global financial meltdown of 2008 and the ensuing collapse of the oil price caused further chaos. This was followed by mass demonstrations against the Russian government in 2011-12; the conflict 
in Ukraine in 2014 and the resulting Western sanctions against the Russian petroleum industry; and the collapse of the oil price and the Russian rouble in 2014. Meanwhile, the Soviet Union's former enemy, China, rose to become the world's biggest gross oil importer in 2018, in the context of the growing international isolation of Russia and the deterioration of its relations with the Western world.

Obviously, several of these developments also had implications for the Western oil companies; however, the Russians had to deal with a whole raft of additional domestic and international issues which did not concern their Western counterparts. In addition, the Western oil companies did not prove any better at predicting the future than their Russian counterparts; none of them foresaw the developments in Ukraine and their consequences for the relationships between Russia and the West. The Russian oil companies that survived the 1990s learned how to change with changing times and adapt to the new rules of the game when Vladimir Putin came to power and launched the étatization of the economy (Godzimirski 2018).

Having examined Russia's five largest oil companies and how they respond to a changing environment, we find that they are in fact masters of change. The simultaneous oil price collapse and introduction of sanctions in 2014 might have been enough to wipe them out, but the companies appear to have escaped more or less unscathed. Some of the points presented as part of the hypothesis in the introduction to this book - that Russian companies are characterized by short-termism and a grab-and-run mentality, that they thrive on assets created during the Soviet period and are unwilling or unable to invest in new developments, that Russian society is fundamentally conservative - are challenged by our findings.

Also as a people, one cannot say that Russians are strangers to change. Over the past century and a half, they have faced more dramatic changes than most peoples, including the abrupt transition from the conservative tsarist regime to Soviet communism and Stalinism, two world wars which were particularly bloody for Russia, and the collapse of the Soviet Union and its entire socio-economic system.

\section{SURVIVAL OF THE FITTEST}

A possible explanation for the resilience of Russia's oil majors is that they are the survivors of the cut-throat post-Soviet period, which only the fittest survived. Many companies were gobbled up: Bashneft, Itera, Sibneft, TNK-BP and YUKOS, to name a few. Also, many of the most powerful oilmen of the early post-Soviet period, such as Victor Ageev, Victor Gorodilov, Sergei Muravlenko and Anatoliy Fomin, had to concede defeat. By contrast, Vagit Alekperov (see the chapter on LUKOIL) and Vladimir Bogdanov (see the 
chapter on Surgutneftegas) were strong and able to adapt to change, while Alekperov even anticipated and initiated some change himself. The Russian oil industry is mostly about people - larger-than-life personalities who know how to move with the times, not only adapting to, but in some cases writing the new rules of the game.

In her 2008 study of organizational transformation in the Russian oil industry, Dixon (2008) somewhat paradoxically admired TNK-BP and YUKOS for their innovativeness, openness to external impulses and efficiency while casting LUKOIL and Surgutneftegas as inefficient and authoritarian relics of Soviet management culture. Today, LUKOIL and Surgutneftegas are doing fine while TNK-BP and YUKOS have been cannibalized by their peers. Clearly, LUKOIL and Surgutneftegas had something that TNK-BP and YUKOS lacked: the ability to cope with a changing environment not through innovation and revolution but through political savviness, discipline, stability and stoicism. What Western commentators have interpreted as stagnation and outdatedness may have turned out to be strengths in Russia's post-Soviet business environment. LUKOIL and Surgutneftegas understood what was needed to survive and prosper in Russia, and did so better than YUKOS.

Dixon (2008, p. 41) writes: 'Traditional Russian organisations are characterised by a command-and-control approach which is manifested in authoritarianism, obedience to authority, the use of coercive power, and an emphasis on rank and status.' This point finds strong support in the broader literature (see Henry and Sundstrom 2007; Husted et al. 2012; Kets de Vries 2001; Kogut and Zander 2000; Kornai 1992; Kryukov and Moe 2018; McCarthy et al. 2005; Vlachoutsicos and Lawrence 1996).

Also, we find that Russian oil and gas companies are characterized by a highly hierarchical, top-down structure. Employees fear making errors, being blamed for errors, or being swept out in crackdowns or changes of management. Disobedience and failure to carry out orders are often punished harshly. Staff may not only be fired by their current employer, but de facto banned from working for any company in the industry. Such a culture of fear is not conducive to organizational foresight. Thus, one possible interpretation is that, due to hierarchies and discipline, Russian oil companies are indeed not very good at foreseeing changes, but the same discipline makes them robust and able to handle changes once they occur. The fact that they have a lot of practice dealing with dramatic changes may also make them skilled at it.

\section{A NOTE OF CAUTION: RUSSIA HAS NO TESLA}

In this book, we have focused on Russia's five main oil companies because of the decisive impact of their performance on Russia's petroleum sector and hence the performance of the Russian economy and the strength of the Russian 
state. Although we have ended up granting Russian oil majors a clean bill of health as oil companies, this does not mean that Russia and the Russian petroleum sector are immune to the changes in international oil demand arising from climate policy. Russia may have well-managed oil companies; however, it hardly has many things other than these companies; in other words, it has few other companies positioned to take on an important role in a decarbonized world.

Western actors are not necessarily better at predicting the future, but they are more diverse. For example, the two American companies ExxonMobil and Tesla embody diametrically opposite visions of where the world is headed. This means that whichever vision is right, the United States, as a country, has a bet on it. Russia's bets, however, are less diversified, and that is a vulnerability.

\section{REFERENCES}

Dixon, S. (2008), Organisational Transformation in the Russian Oil Industry, Cheltenham, UK and Northampton, MA, USA: Edward Elgar.

Fjaertoft, D. and I. Overland (2015), 'Financial sanctions impact Russian oil, equipment export ban's effects limited', Oil \& Gas Journal, 113 (8), 66-72, accessed 25 April 2020 at https://www.researchgate.net/publication/281776234_Financial Sanctions_Impact_Russian_Oil_Equipment_Export_Ban's_Effects_Limited.

GKS (2019), 'Prosmyshlennoe proizvodstvo', accessed 27 January 2019 at http://www .gks.ru/wps/wcm/connect/rosstat_main/rosstat/ru/statistics/enterprise/industrial/\#.

Godzimirski, J. (2018), The Political Economy of Russian Aluminium: Between the Dual State and Global Markets, London: Palgrave Macmillan.

Henry, L.A. and L.M. Sundstrom (2007), 'Russia and the Kyoto Protocol: Seeking an alignment of interests and image', Global Environmental Politics, 7 (4), 47-69.

Husted, K., S. Michailova, D.B. Minbaeva and T. Pedersen (2012), 'Knowledge-sharing hostility and governance mechanisms: An empirical test', Journal of Knowledge Management, 16 (5), 754-73.

Kets de Vries, M.F.R. (2001), 'The anarchist within: Clinical reflections on Russian character and leadership style', Human Relations, 52 (5), 585-627.

Kogut, B. and U. Zander (2000), 'Did socialism fail to innovate? A natural experiment of the two Zeiss companies', American Sociological Review, 65 (2), 169-90.

Kornai, J. (1992), The Socialist System: The Political Economy of Communism, Oxford and New York: Oxford University Press.

Kryukov, V. and A. Moe (2018), 'Does Russian unconventional oil have a future?', Energy Policy, 119, 41-50.

McCarthy, D., S. Puffer, O. Vikhanski and A. Naumov (2005), 'Russian managers in the new Europe: Need for a new management style', Organizational Dynamics, 34 (3), 231-46.

MinEnergo (2019), 'Statistika', accessed 27 January 2019 at https://minenergo.gov.ru/ activity/statistic.

Overland, I. (2011), 'Modernization after Medvedev?', Russian Analytical Digest, 105, $2-4$.

Popper, K. (1959), The Logic of Scientific Discovery, London: Hutchinson. 
Putin, V. (2017), 'O chem rasskazal Vladimir Putin ya plenarnom zasedanii PMEF', Rossiyskaya Gazeta, accessed 20 November 2017 at https://rg.ru/2017/06/02/reg -szfo/o-chem-rasskazal-vladimir-putin-na-plenarnom-zasedanii-pmef.html.

Vlachoutsicos, C.A. and P.R. Lawrence (1996), 'How managerial learning can assist economic transformation in Russia', Organization Studies, 17 (2), 311-25. 